\title{
PENGARUH PEMBELAJARAN BERBASIS MASALAH TERSTRUKTUR TERHADAP KEMAMPUAN PENALARAN MATEMATIS MAHASISWA PENDIDIKAN MATEMATIKA UIN WALISONGO SEMARANG
}

\author{
Emy Siswanah * \\ Jurusan Matematika Fakultas Sainstek UIN Walisongo Semarang \\ E-mail : emysis_math@yahoo.com
}

\begin{abstract}
Abstrak
Pokok permasalahan dalam penelitian ini adalah apakah terdapat pengaruh pembelajaran berbasis masalah terstruktur terhadap kemampuan penalaran matematis mahasiswa Pendidikan Matematika UIN Walisongo Semarang. Penelitian ini merupakan penelitian eksperimen dengan rancangan penelitian Posttest Comparations Group Design. Populasi dalam penelitian ini adalah seluruh mahasiswa Semester I Pendidikan Matematika UIN Walisongo Semarang Tahun Akademik 2014/2015 yang berjumlah 97 mahasiswa. Instrumen yang digunakan untuk mengumpulkan data penelitian adalah tes uraian. Data penelitian dianalisis menggunakan uji normalitas, homogenitas, dan uji-t (independent sample t-test). Uji-t dilakukan untuk mengetahui perebedaan kemampuan penalaran matematis mahasiswa. Berdasarkan hasil analisis data diperoleh nilai t hitung adalah 2,994 dan t tabel 1,671. Karena thitung lebih dari t tabel maka dapat disimpulkan bahwa ada pengaruh penggunaan model pembelajaran berbasis masalah terstruktur terhadap kemampuan penalaran matematis mahasiswa.
\end{abstract}

Kata Kunci : pembelajaran berbasis masalah, kemampuan penalaran matematis 


\section{PENDAHULUAN}

Setiap mata pelajaran mempunyai karakteristik yang unik, begitu juga dengan matematika yang diajarkan dari pendidikan dasar sampai pendidikan tinggi. Sehingga dalam mengajarkan matematika diperlukan pemahaman yang utuh terhadap karakteristik matematika agar pembelajaran matematika lebih komprehensif.

Matematika merupakan ilmu yang mempunyai ciri-ciri khusus, salah satunya adalah penalaran dalam matematika yang bersifat deduktif yang berkenaan dengan ide-ide, konsep-konsep, dan simbol-simbol yang abstrak serta tersusun secara hierarkis. Oleh karena itu, pembelajaran matematika hendaknya disajikan secara sistematis, teratur, dan logis, sesuai dengan perkembangan intelektualnya. Itulah sebabnya, sajian matematika yang diberikan kepada peserta didik sesuai dengan jenjang pendidikannya. Peserta didik pada tingkat dasar, sajian matematikanya bersifat konkret, semakin tinggi jenjang pendidikannya, maka sajian matematikanya semakin abstrak.

Berdasarkan peraturan Menteri Pendidikan Nasional (Permendiknas) Republik Indonesia No. 22 Tahun 2006 (tentang Standar Isi) pendidikan matematika mulai sekolah dasar hingga menengah atas bertujuan agar peserta didik memiliki kemampuan salah satunya adalah "menggunakan penalaran pada pola dan sifat, melakukan manipulasi matematika dalam membuat generalisasi, menyusun bukti atau menjelaskan gagasan dan pernyataan matematika".

Berkaitan dengan kemampuan penalaran matematis, sebagian besar pembelajaran matematika baik di sekolah maupun di perguruan tinggi melibatkan kemampuan penalaran matematis. Bila kemampuan penalaran tidak dikembangkan kepada peserta didik maka bagi peserta didik matematika hanya akan menjadi materi yang mengikuti serangkaian prosedur dan meniru contoh-contoh tanpa mengetahui maknanya. Dengan belajar matematika, keterampilan berpikir peserta didik akan meningkat karena pola pikir yang dikembangkan dalam pembelajaran matematika membutuhkan dan melibatkan pemikiran kritis, sistematis, logis, dan kreatif, sehingga peserta didik mampu menarik kesimpulan dari berbagai fakta atau data yang mereka dapatkan atau ketahui. Shadiq (2007) menjelaskan bahwa "kemampuan penalaran tidak hanya dibutuhkan peserta didik ketika mereka belajar matematika tetapi dibutuhkan agar kelak mereka menjadi manusia yang dapat menganalisis setiap masalah yang muncul secara jernih, memecahkan masalah secara tepat, dapat menilai sesuatu secara kritis dan objektif serta dapat menarik kesimpulan secara logis". 
Mengingat pentingnya kemampuan penalaran matematis dalam pembelajaran matematika maka guru dan dosen diharapkan mampu merencanakan pembelajaran dengan metode dan model pembelajaran yang inovatif dan variatif agar penalaran dan kemandirian belajar matematika peserta didik menjadi lebih baik. Salah satu model inovatif yang dapat diterapkan adalah pembelajaran berbasis masalah terstruktur. Pembelajaran berbasis masalah merupakan suatu startegi yang dimulai dengan menghadapkan peserta didik pada masalah keseharian yang nyata (authentic) atau masalah yang disimulasikan sehingga peserta didik dituntut berpikir kritis dan menempatkan peserta didik sebagai problem solver.

Oleh karena itu, dalam pembelajaran matematika diharapkan dapat menerapkan pendekatan yang mendidik secara kreatif, yaitu diantaranya dapat menggunakan matematisasi horizontal dan vertikal untuk menyelesaikan masalah matematika dan masalah dalam dunia nyata. Pembelajaran matematika hendaknya dimulai dengan pengenalan masalah atau mengajukan masalah riil atau nyata, yaitu pembelajaran yang mengaitkan dengan kehidupan sehari-hari peserta didik, kemudian peserta didik secara bertahap dibimbing untuk menguasai konsep matematika dengan melibatkan peran aktif peserta didik dalam proses pembelajaran. Hal inilah yang menjadi inspirasi bagi penulis untuk mengetahui bagaimana pengaruh pembelajaran berbasis masalah terstruktur terhadap kemampuan penalaran matematis dan kemandirian belajar matematika mahasiswa pendidikan matematika UIN Walisongo Semarang.

Dalam penelitian ini akan dibahas apakah terdapat pengaruh pembelajaran berbasis masalah terstruktur terhadap kemampuan penalaran matematis mahasiswa Pendidikan Matematika UIN Walisongo Semarang. Penelitian ini difokuskan pada pembelajaran berbasis masalah terstuktur mata kuliah trigonometri, bab Perbandingan Trigonometri. Objek penelitian ini dibatasi pada mahasiswa semester I Pendidikan Matematika UIN Walisongo Semarang.

Pada pembelajaran berbasis masalah terstruktur peserta didik dihadapkan dengan masalah di awal pembelajarannya. Masalah ini terbagi ke dalam sub-sub masalah, yang dapat dikembangkan pada bahan ajar yang akan diberikan dalam pembelajaran. Pembelajaran berbasis masalah terstruktur dalam implementasinya tidak jauh berbeda dengan pembelajaran berbasis masalah terbuka (open-ended). Pembelajaran berbasis masalah terstruktur dapat juga didefinisikan sebagai pembelajaran berbasis masalah yang masalahnya dijabarkan ke dalam sub-sub masalah yang bergradasi dari khusus menuju umum atau dari sederhana menuju kompleks. 
Jadi, PBM adalah suatu pendekatan pembelajaran yang menggunakan masalah dunia nyata sebagai suatu konteks bagi peserta didik untuk belajar tentang cara berpikir kritis, kemampuan penalaran, dan keterampilan pemecahan masalah, serta untuk memperoleh pengetahuan dan konsep yang esensial dari materi kuliah atau materi pelajaran.

Karakteristik PBM menurut Fathurrohman adalah sebagai berikut :
a. Belajar diawali dengan masalah
b. Masalah yang diberikan berhubungan dengan dunia nyata peserta didik
c. Mengorganisasikan pelajaran seputar masalah
d. Mahasisawa diberikan tanggungjawab yang besar untuk melakukan proses belajar secara mandiri
e. Menggunakan kelompok kecil
f. Mahasiswa dituntut untuk mendemonstrasikan apa yang telah dipelajari dalam bentuk kinerja

Menurut Arends (Trianto, 2009) pembelajaran berbasis masalah (PBM) merupakan suatu pendekatan pembelajaran di mana peserta didik mengerjakan permasalahan yang autentik dengan maksud untuk menyusun pengetahuan mereka sendiri, mengembangkan inkuiri dan keterampilan berpikir, kemampuan penalaran, mengembangkan kemandirian, dan percaya diri.

Pada pembelajaran berbasis masalah peserta didik didorong belajar aktif dengan konsep-konsep dan prinsip-prinsip. Peserta didik didorong menghubungkan pengalaman yang telah dimiliki dengan pengalaman baru yang dihadapi sehingga peserta didik menemukan prinsip-prinsi baru. Peserta didik dimotivasi menyelesaikan pekerjaannya sampai mereka menemukan jawaban-jawaban atas problem yang dihadapi mereka. Peserta didik berusaha belajar mandiri dalam memecahkan masalah dengan mengembangkan kemampuan menganalisis dan mengelola informasi. Pembelajaran berbasis masalah membantu peserta didik memahami struktur atau ide-ide kunci suatu disiplin (Suprijono, 2009).

Penalaran matematika (Thontowi, 1993) adalah proses berpikir secara logis dalam menghadapi problema dengan mengikuti ketentuan-ketentuan yang ada. Proses penalaran matematika diakhiri dengan memperoleh kesimpulan. Referensi lain yaitu Math Glossary (http://www.surfnetparents.com) menyatakan definisi penalaran matematis sebagai berikut, "Mathematical reasoning: thinking through math problems logically in order to arrive at solutions. It involves being able to identify what is important and unimportant in solving a problem and to explain or justify a solution." 
Menurut Krismanto (1997), di dalam mempelajari matematika kemampuan penalaran dapat dikembangkan pada saat peserta didik memahami suatu konsep (pengertian), atau menemukan dan membuktikan suatu prinsip. Ketika menemukan atau membuktikan suatu prinsip, dikembangkan pola pikir induktif dan deduktif. Peserta didik dibiasakan melihat ciri-ciri beberapa kasus, melihat pola dan membuat dugaan tentang hubungan yang ada diantara kasus-kasus itu, serta selanjutnya menyatakan hubungan yang berlaku umum (generalisasi, penalaran induktif). Disamping itu peserta didik juga perlu dibiasakan menerima terlebih dahulu suatu hubungan yang jelas kebenarannya, selanjutnya menggunakan hubungan itu untuk menemukan hubungan-hubungan lainnya (penalaran deduktif). Jadi baik penalaran deduktif maupun induktif, keduanya amat penting dalam pembelajaran matematika.

Kemampuan penalaran matematis peserta didik dalam pembelajaran matematika perlu dikembangkan. Telah dijelaskan pada dokumen Peraturan Dirjen Dikdasemen melalui Peraturan No. 506/C/PP/2004, penalaran dan komunikasi merupakan kompetensi yang ditunjukkan peserta didik dalam melakukan penalaran dan mengkomunikasikan gagasan matematika. Menurut dokumen di atas indikator yang menunjukkan adanya penalaran menurut TIM PPPG Matematika (Romadhina, 2007) antara lain:

a. Menyajikan pernyataan matematika secara lisan, tertulis, gambar dan diagram.

b. Mengajukan dugaan (conjegtures)

c. Melakukan manipulasi matematika

d. Menarik kesimpulan, menyusun bukti, memberikan alasan atau bukti terhadap beberapa solusi

e. Menarik kesimpulan dari pernyataan

f. Memeriksa kesahihan suatu argumen

g. Menentukan pola atau sifat dari gejala matematis untuk membuat generalisasi.

Tujuh indikator menurut TIM PPPG Matematika di atas akan digunakan dalam penelitian ini.

\section{METODE PENELITIAN}

Metode penelitian yang digunakan dalam penelitian ini adalah metode eksperimen. Pada penelitian ini ada dua kelompok subjek penelitian yaitu kelompok eksperimen dan kelompok kontrol. Kelompok eksperimen mendapat perlakuan pembelajaran matematika dengan model pembelajaran berbasis masalah terstruktur dan kelompok kontrol dengan perlakuan pembelajaran konvensional. Setelah selesai perlakuan, kedua kelompok diberikan tes uraian dengan menggunakan instrumen yang sama. Desain eksperimen yang digunakan dalam penelitian ini adalah Randomized Control Group Posttest Only Design. 
Desain penelitian yang akan dilaksanakan dapat dijelaskan melalui tabel 1 .

Tabel 1. Desain Penelitian

\begin{tabular}{|c|c|c|}
\hline Kelas & Perlakuan & Post test \\
\hline Eksperimen (E) & A & Y \\
\hline Kontrol (C) & B & Y \\
\hline
\end{tabular}

(Sudjana dan Ibrahim, 1989)

Keterangan:

A : Pembelajaran berbasis masalah terstruktur

B : Pembelajaran konvensional

Y : Post test

Populasi dalam penelitian ini adalah seluruh mahasiswa Semester I Pendidikan Matematika UIN Walisongo Semarang Tahun Akademik 2014/2015 yang berjumlah 97 mahasiswa. Mahasiswa Semester I Pendidikan Matematika terbagi menjadi 3 kelas yaitu TM-1A, TM-1B, dan TM-1C. Kelas TM-1A terdiri dari 33 mahasiswa, TM-1B terdiri dari 28 mahasiswa, dan jumlah mahasiswa di kelas TM-1C adalah 36 mahasiswa.

Sampel dalam penelitian ini ditentukan dengan menggunakan cluster random sampling. Dari tiga kelas yang ada, yaitu TM-1A, TM-1B, dan TM-1C dipilih secara acak melalui undian untuk menentukan kelas eksperimen dan kelas kontrol. Berdasarkan hasil pengundian, kelas TM-1A terpilih sebagai kelas kontrol dan TM-1B terpilih sebagai kelas eksperimen. Sehingga jumlah sampel dalam penelitian ini adalah 61 mahasiswa

Instrumen yang digunakan untuk mengumpulkan data penelitian adalah tes uraian (posttest). Sebelum tes uraian (posttest) diberikan kepada kedua kelas sampel, yaitu kelas eksperimen dan kelas kontrol maka tes uraian tersebut diujicobakan pada kelas yang bukan merupakan kelas sampel. Hal ini dilakukan untuk mengetahui validitas dan reliabilitas tes. Tes uraian yang diujicobakan tediri dari 6 soal. Berdasarkan hasil perhitungan menggunakan rumus korelasi produk moment diperoleh bahwa dari 6 soal, 4 soal dinyatakan valid dan 2 soal tidak valid. Reliabilitas tes uraian tergolong tinggi dengan nilai Cronbach-alpha adalah $r_{i}=0,611$.

Data yang sudah diperoleh kemudian dianalisis. Tes uraian (posttest) dianalisis menggunakan uji-t pihak kanan. Hipotesis statistik yang diuji adalah:

$$
\begin{aligned}
\mathrm{H}_{0}: & \mu_{1} \leq \mu_{2} \\
\mathrm{H}_{1} & : \mu_{1}>\mu_{2} \\
\mu_{1}: & \text { rata-rata posttest kemampuan penalaran matematis kelas eksperimen yang } \\
& \text { menerapkan pembelajaran berbasis masalah terstruktur. }
\end{aligned}
$$


$\mu_{2}$ : rata-rata posttest kemampuan penalaran matematis kelas kontrol yang pembelajarannya dilaksanakan secara konvensional.

Menurut Sudjana (2005) uji hipotesis ini menggunakan rumus t tes yaitu

$$
t=\frac{\bar{X}_{1}-\bar{X}_{2}}{S \sqrt{\frac{1}{n_{1}}+\frac{1}{n_{2}}}}
$$

dengan :

$$
s^{2}=\frac{\left(n_{1}-1\right) s_{1}^{2}+\left(n_{2}+1\right) s_{2}^{2}}{n_{1}+n_{2}-2}
$$

Dimana:

$$
\begin{aligned}
& s_{1}^{2}=\frac{n_{1} \sum x_{1}^{2}-\left(\sum x_{1}\right)^{2}}{n_{1}\left(n_{1}-1\right)} \\
& s_{2}^{2}=\frac{n_{2} \sum x_{2}^{2}-\left(\sum x_{2}\right)^{2}}{n_{2}\left(n_{2}-1\right)}
\end{aligned}
$$

\section{Keterangan:}

$s_{1}^{2}=$ varian kelas eksperimen

$s_{2}^{2}=$ varian kelas kontrol

$s^{2}=$ varian gabungan

$\bar{X}_{1}=$ rata-rata skor kemampuan penalaran matematis kelas eksperimen

$\bar{X}_{2}=$ rata-rata skor kemampuan penalaran matematis kelas kontrol

$n_{1}=$ jumlah subyek kelas eksperimen

$n_{2}=$ jumlah subyek kelas kontrol

Derajat kebebasan untuk tabel distribusi $t$ adalah $\left(\mathrm{n}_{1}+\mathrm{n}_{2}-2\right)$ dengan peluang (1- $\left.\alpha\right)$, dan $\alpha$ taraf signifikan (Sudjana, 2005). Dalam penelitian ini diambil taraf signifikan $\alpha=5 \%$.

Dalam uji perbedaan dua rata-rata nilai posttest, kriteria pengujiannya sebagai berikut:

1. $\mathrm{H}_{0}$ diterima jika $\mathrm{t}_{\text {hitung }}<\mathrm{t}_{(1-1 / 2 \alpha)}(\mathrm{n} 1+\mathrm{n} 2-2)$, hal ini berarti rata-rata skor kemampuan penalaran matematis kelas eksperimen kurang dari atau sama dengan rata-rata skor kemampuan penalaran matematis kelas kontrol, sehingga dapat dikatakan bahwa 
penerapan pembelajaran berbasis masalah terstruktur tidak efektif untuk meningkatkan kemampuan penalaran matematis mahasiswa Pendidikan Matematika UIN Walisongo.

2. $H_{1}$ terima jika $t_{\text {hitung }} \geq t_{(1-1 / 2 \alpha)(n 1+n 2-2)}$, hal ini berarti rata-rata skor kemampuan penalaran matematis kelas eksperimen lebih dari rata-rata skor kemampuan penalaran matematis kelas kontrol, sehingga dapat dikatakan bahwa penerapan pembelajaran berbasis masalah terstruktur efektif untuk meningkatkan kemampuan penalaran matematis mahasiswa Pendidikan Matematika UIN Walisongo.

\section{HASIL PENELITIAN DAN PEMBAHASAN}

\section{Hasil Penelitian}

Setelah dilakukan proses pembelajaran pada kelas eksperimen dan kelas kontrol selanjutnya diberikan tes akhir (posttest). Hasil posttest dianalisis untuk mengetahui apakah ada perbedaan kemampuan penalaran matematis. Berdasarkan hasil tes akhir, pada kelas eksperimen diperoleh skor tertinggi 11 dan skor terendah 1 dengan nilai rata-rata kelas 6.89 dan standar deviasi 2.97. Sedangkan pada kelas kontrol diperoleh skor tertinggi 12 dan skor terendah 0 dengan nilai rata-rata kelas 4.39 dan standar deviasi 3.46.

Sebelum data dianalisa menggunakan uji-t pihak kanan maka terlebih dahulu diuji normalitas dan homogenitas data. Uji normalitas data nilai posttest dilakukan dengan rumus Kolmogorov-Smirnov menggunakan SPSS. Dari hasil output SPSS diperoleh nilai signifikasnsi untuk kelas ekaperimen adalah 0,136 dan kelas kontrol adalah 0.093. Karena nilai signifikasi kelas eksperimen dan kelas kontrol masing-masing > 0.05 maka $\mathrm{H}_{0}$ diterima. Jadi, kelas eksperimen dan kelas kontrol berdistribusi normal. Uji homogenitas data nilai posttest kedua kelas sampel dilakukan dengan uji Levene menggunakan SPSS. Berdasarkan data output SPSS untuk uji homogenitas diperoleh nilai signifikansi (sig.) 0.201. Nilai tersebut $>0.05$ maka $\mathrm{H}_{0}$ diterima. Hal ini berarti kedua kelas sampel mempunyai varians yang sama.

Uji t pihak kanan digunakan untuk mengetahui apakah model pembelajaran berbasis masalah terstruktur mempunyai pengaruh yang signifikan terhadap kemampuan penalaran matematis mahasiswa. Dari hasil perhitungan SPSS diperoleh nilai $\mathrm{t}=2,994$ (lampiran 23). Nilai t tabel untuk $\mathrm{dk}=59$ dan $\alpha=5 \%$ adalah 1,671. Hasil uji t satu pihak dapat dilihat pada tabel di bawah ini :

Tabel uji t satu pihak

\begin{tabular}{|l|l|l|l|}
\hline Data & $\mathrm{t}_{\text {hitung }}$ & $\mathrm{t}_{\text {tabel }}$ & Kriteria \\
\hline Posttest & 2,994 & 1,671 & $\mathrm{H}_{1}$ diterima \\
\hline
\end{tabular}


Dari tabel di atas dapat diketahui bahwa $\mathrm{H}_{1}$ diterima artinya nilai rata-rata kemampuan penalaran matematis kelas eksperimen lebih tinggi daripada rata-rata kemampuan penalaran matematis kelas kontrol. Hal ini berarti penerapan pembelajaran terstruktur memberikan pengaruh yang signifikan dalam meningkatkan kemampuan penalaran matematis mahasiswa pendidikan matematika UIN Walisongo Semarang. Dengan demikian dapat dikatakan bahwa penerapan pembelajaran berbasis masalah terstruktur efektif dalam meningkatkan kemampuan penalaran matematis mahasiswa Pendidikan Matematika UIN Walisongo Semarang.

\section{Pembahasan}

Hasil penelitian ini menunjukkan bahwa untuk meningkatkan kemampuan penalaran matematis mahasiswa maka perlu digunakan model pembelajaran yang sesuai. Salah satu model pembelajaran yang sesuai adalah model pembelajaran berbasis masalah terstruktur. Pada model pembelajaran berbasis masalah terstruktur, dosen memberikan masalah-masalah kepada mahasiswa untuk melatih logika berpikir mahasiswa bagaimana menyelesaikan masalah tersebut. Selain itu, melalui masalah yang diberikan, mahasiswa membangun pengetahuan mereka sendiri untuk memecahkan masalah tersebut.

Materi perbandingan trigonometri mempunyai penerapan dalam kehidupan seharihari, diantaranya untuk mengukur tinggi bangunan, mengukur jarak, keperluan navigasi, dan lain-lain. Masalah yang diberikan kepada mahasiswa merupakan masalah yang masih berhubungan dengan penerapan perbandingan trigonometri dalam kehidupan sehari-hari. Hal ini dilakukan agar mahasiswa menjadi lebih tertarik untuk menyelesaikan masalah yang diberikan.

Masalah dalam model pembelajaran berbasis masalah adalah masalah yang bersifat terbuka. Mahasiswa dapat mengembangkan berbagai macam kemungkinan jawaban berdasarkan pengetahuan yang dapat dibangun oleh mereka. Artinya jawaban dari masalah tersebut bisa menggunakan berbagai cara. Hal ini seperti yang terlihat dari penyelesaian masalah yang dituliskan kelompok pada kelas eksperimen. Kelompok 1 dan kelompok 2 menyelesaikan masalah tersebut dengan cara yang berbeda tetapi memberikan hasil akhir yang sama. Dan kedua cara tersebut benar.

Hal ini membuktikan bahwa mahasiswa menyelesaikan masalah dengan membangun pengetahuan mereka sendiri. Hal ini seperti yang dinyatakan oleh Arends (Trianto, 2009) bahwa pembelajaran berbasis masalah (PBM) merupakan suatu pendekatan 
pembelajaran di mana peserta didik mengerjakan permasalahan yang autentik dengan maksud untuk menyusun pengetahuan mereka sendiri, mengembangkan inkuiri dan keterampilan berpikir, kemampuan penalaran, mengembangkan kemandirian, dan percaya diri.

Dalam menyelesaikan permasalahan yang diberikan dosen, mahasiswa mampu berpikir logis sehingga mampu mengembangkan kemampuan penalaran matematis mereka. Cara mahasiswa menyelesaikan masalah menunjukkan bahwa mahasiswa telah menggunakan kemampuan penalaran matematis yang sesuai dengan tujuh indikator menurut TIM PPPG Matematika. Tujuh indikator tersebut adalah menyajikan pernyataan matematika secara lisan, tertulis, gambar dan diagram; mengajukan dugaan (conjegtures); melakukan manipulasi matematika; menarik kesimpulan, menyusun bukti, memberikan alasan atau bukti terhadap beberapa solusi; menarik kesimpulan dari pernyataan; memeriksa kesahihan suatu argumen; menentukan pola atau sifat dari gejala matematis untuk membuat generalisasi.

PBM membuat mahasiswa mampu menganalisis masalah dan menggunakan penalaran matematis mereka untuk menyelesaikan permasalahan tersebut. PBM mencoba untuk membuat mahasiswa lebih bertanggung jawab dalam pembelajaran, daripada sekedar menjadi penerima informasi yang pasif, mahasiswa dididik untuk bertanya, menemukan informasi yang relevan, dan merancang solusi-solusi untuk masalah open ended. Mahasiswa mencari dan mengumpulkan informasi dari berbagai sumber kemudian mengolah informasi tersebut untuk menjadi solusi dari permasalahan. Hal ini tercermin dari jawaban mahasiswa dalam menyelesaikan masalah. Mahasiswa mampu menggunakan bermacam rumus yang telah mereka pelajari untuk menjawaban permasalahan yang ada.

Dalam pembelajaran trigonometri menggunakan pembelajaran berbasis masalah, mahasiswa tidak hanya menghapal rumus dan mengerjakan latihan saja, namun mahasiswa memahami konsep dan membangun pemahaman, mahasiswa juga mampu menerapkan ilmu perbandingan trigonometri untuk memecahkan masalah yang berhubungan dengan kehidupan sehari-hari.

Pada pembelajaran berbasis masalah mahasiswa didorong belajar aktif dengan konsep-konsep dan prinsip-prinsip. Mahasiswa didorong menghubungkan pengetahuan yang telah dimiliki dengan pengetahuan baru yang dihadapi sehingga mahasiswa mampu mengembangkan kemampuan menganalisis, mengembangan kemampuan penalaran matematis, dan mengelola informasi. Hal ini seperti yang dinyatakan (Suprijono, 2009). 


\section{KESIMPULAN}

Dari hasil penelitian yang telah dilakukan maka dapat disimpulkan bahwa terdapat pengaruh penggunaan model pembelajaran berbasis masalah terstruktur terhadap kemampuan penalaran matematis mahasiswa Tadris Matematika IAIN Walisongo Semarang. Hal ini berdasarkan hasil perhitungan uji t pihak kanan menggunakan SPSS diperoleh $\mathrm{t}_{\text {hitung }}=2,994$ sementara $\mathrm{t}_{\text {tabel }}$ dengan $\mathrm{dk}=59$ dan $\alpha=5 \%$ adalah 1,671 . Karena $t_{\text {hitung }}>t_{\text {tabel }}$ maka $\mathrm{H}_{1}$ diterima. Jadi, dapat dikatakan bahwa skor rata-rata kemampuan penalaran matematis kelas eksperimen lebih tinggi daripada skor rata-rata kemampuan penalaran matematis kelas kontrol atau dengan kata lain skor rata-rata kemampuan penalaran matematis yang menggunakan model pembelajaran berbasis masalah terstruktur lebih tinggi daripada skor rata-rata kemampuan penalaran matematis yang pembelajarannya dilaksanakan secara konvensional. 


\section{DAFTAR PUSTAKA}

Fathurrohman. Pembelajaran Berbasis Masalah. Dikdas UNY. Tersedia dalam http://staff.uny.ac.id/sites/default/files/pendidikan/Fathurrohman,\%20S.Pd.,M.P d/Pembelajaran\%20Berbasis\%20Masalah.pdf. (Diakses 30 Maret 2014).

Krismanto, Al. 1997. Pengelolaan Belajar Mengajar Matematika SMU dan beberapa Permasalahannya. Yogyakarta: IKIP Yogyakarta.

Marzuki, A. 2006. Implementasi Pembelajaran Kooperatif (Cooperative Learning) Dalam Upaya Meningkatkan Kemampuan Koneksi dan Pemecahan Masalah Matematik Siswa. Tesis pada PPS UPI. Bandung.

Math Glossary . http://www.surfnetparents.com. (Diakses tanggal 1 April 2014).

Romadhina, Dian. 2007. Pengaruh Kemampuan Penalaran dan Kemampuan Komunikasi Matematik terhadap Kemampuan Menyelesaikan Soal Cerita pada Pokok Bahasan Bangun Ruang Sisi Lengkung Siswa Kelas IX SMP Negeri 29 Semarang melalui Model Pembelajaran Pemecahan Masalah. http://digilib.unnes.ac.id/gsdl/collect/skripsi/archives/HASHf1de/c0fe599f.dir/do c.pdf. (Diakses tanggal 2 April 2014).

Shadiq, Fajar. 2007. Penalaran atau Reasoning : Mengapa Perlu Dipelajari Para Siswa di Sekolah? Tersedia dalam http://fadjarp3g.files.wordpress.com/2007/09/okpenalaran_gerbang_.pdf. (diakses tanggl 5 April 2014)

Sudjana, Nana dan Ibrahim. 1989. Penelitian dan Penilaian Pendidikan. Bandung : Sinar Baru

Sudjana, Nana. 2005. Metode Statistik. Bandung : Tarsito

Suprijono, Agus. 2009. Cooperative Learning Teori dan Aplikasi Paikem. Jakarta: Pustaka Pelajar.

Thontowi, Ahmad. 1993. Psikologi Pendidikan. Bandung: Angkasa.

Trianto. 2007. Model-Model Pembelajaran Inovatif Berorientasi Kontruktivistik. Jakarta: Prestasi Pustaka. 